\title{
HUBUNGAN ANTARA UMUR DAN PARITAS IBU HAMIL DENGAN FREKUENSI PEMERIKSAAN KEHAMILAN DI KLINIK BUDI MULIA MEDIKA PALEMBANG
}

Leny

Akademi Kebidanan Budi Mulia Palembang

\section{Informasi Artikel :}

Diterima : $\quad$ Maret 2019

Disetujui : Juni 2019

"Korespondensi Penulis :

basorirayca@gmail.com

\begin{abstract}
A B S T R A K
Menurut World Health Organization (WHO), memperkirakan kematian ibu sebanyak 500.000 kematian setiap tahun, 99\% diantaranya terjadi di negara berkembang. Faktor-faktor yang mempengaruhi frekuensi pemeriksaan kehamilan antara lain paritas ibu, usia ibu, pengetahuan, sikap, ekonomi, sosial budaya, dukungan keluarga, keadaan geografis dan informasi ibu mengenai frekuensi pemeriksaan kehamilan. Tujuan Penelitian ini adalah untuk mengetahui hubungan antara umur dan paritas dengan frekuensi pemeriksaan kehamilan di Klinik Budi Mulia Medika Palembang Tahun 2018. Desain penelitian ini adalah survei analitik dengan pendekatan cross sectional. Populasi Penelitian adalah seluruh ibu hamil trimester III yang memeriksakan kehamilan di Klinik Budi Mulia Medika Palembang Tahun 2018. Sampel yang diambil secara simple random sampling dengan jumlah sampel 164 responden. Hasil analisa univariat menujukkan hasil analisa bivariat menggunakan uji statistik Chisquare yang membandingkan $p$ value dengan tingkat kemaknaan $\alpha(0,005)$ menunjukkan bahwa ada hubungan yang bermakna antara umur dengan frekuensi pemeriksaan kehamilan dimana $p$ value $(0,0043)$ lebih kecil dari $\alpha(0,005)$ dan ada hubungan bermakna antara paritas ibu dengan frekuensi pemeriksaan kehamilan dimana $p$ value $(0,0017)$ lebih kecil dari $\alpha$ $(0,005)$. Pelayanan pemeriksaan kehamilan (Antenatal Care) yang tujuan utamanya adalah mencegah komplikasi obstetrik dan memastikan bahwa komplikasi dideteksi sedini mungkin serta ditangani secara memadai, sehinggga diharapkan dapat menurunkan angka kejadian morbiditas dan mortalitas pada ibu maupun janin.
\end{abstract}

Kata Kunci : Frekuensi Pemeriksaan Kehamilan, Umur, Paritas

\section{ABSTRACT}

According to the World Health Organization (WHO), estimating maternal deaths is 500,000 deaths every year, 99\% of which occur in developing countries. Factors that influence the frequency of prenatal care include maternal parity, maternal age, knowledge, attitudes, economy, socioculture, family support, geographical conditions and maternal information regarding the frequency of antenatal care. The purpose of this study was to determine the relationship between age and parity with the frequency of antenatal care at the Budi Mulia Medika Palembang Clinic in 2018. The design of this study was an analytical survey with a cross sectional approach. The study population was all trimester III pregnant women who examined pregnancy at the Budi Mulia Medika Palembang Clinic in 2018. The samples were taken by simple random sampling with a sample of 164 respondents. The results of univariate analysis showed the results of bivariate analysis using the Chi-square statistical test that compares $p$ value with significance level $\alpha$ (0.005) shows that there is a significant relationship between age and frequency of antenatal care where $p$ value (0.0043) is smaller than $\alpha(0.005)$ and there is a significant relationship between maternal parity and frequency of antenatal care, where $p$ value (0.0017) is smaller than $\alpha(0.005)$. Antenatal Care services whose main purpose is to prevent obstetric complications and ensure that complications are detected as early as possible and handled adequately, so that they are expected to reduce the incidence of morbidity and mortality in both mother and fetus

Keywords : Frequency of Pregnancy Examination, Age, Parity 


\section{PENDAHULUAN}

Perawatan Antenatal adalah pemeriksaan yang sistematik dan teliti pada ibu hamil, perkembangan dan pertumbuhan janin dalam kandungannya serta penanganan ibu hamil dan bayinya saat dilahirkan dalan kondisi yang terbaik (Hanafiah, 2006).

Menurut World Health Organization (WHO), memperkirakan kematian ibu sebanyak 500.000 kematian setiap tahun, 99\% diantaranya terjadi di negara berkembang. Angka kematian ibu (AKI) merupakan salah satu indicator pembanguinan kesehatan dalam RPJM 2015-2019 dan SDGs. Menurut data SDKI, ANgka Kematian Ibu sudah mengalami penurunan pada periode 1994-2012 yaitu pada tahun 1994 sebesar 390 per 100.000 kehahiran hidup, tahun 2002 sebesar 307 per 100.000 kehahiran hidup, tahun 2007 sebesar 228 per 100.000 kehahiran hidup, namun pada 2012 angka kematian ibu kembali meningkat menjadi sebesar 359 per 100. 000 kelahiran hidup dan pada tahun 2015 menjadi 305 per 100.000 kelahiran hidup. Salah satu cara yang paling efektif untuk menurunkan kematian ibu adalah dengan meningkatkan pertolongan persalinan oleh tenaga kesehatan terlatih di fasilitas kesehatan (Muhyasir, 2011).

Komplikasi persalinan sebagian besar dapat dicegah bila kesehatan ibu selama hamil selalu terjaga melalui pemeriksaan antenatal care yang teratur dan pertolongan persalinan yang bersih dan aman. Hal ini dilakukan untuk mencapai sasaran Suitainable Development Goals (SDGs) yaitu mengurangi AKI hingga 70 per 100.000 kelahiran hidup dan Angka Kematian Neonatal hingga 12 per 1.000 kelahiran hidup dan angka kematian balita 25 per 1.000 kelahiran hidup pada tahun 2030 (Depkes, 2018).

Kebijakan Departemen Kesehatan dalam mempercepat penurunan Angka Kematian Ibu (AKI) pada dasarnya mengacu pada intervensi strategis Empat Pilar Safe Mother Hood yaitu Keluarga Berencana, Pelayanan Antenatal Care, Persalinan yang aman, dan Pelayanan Obstetrik, hal yang terpenting adalah Pilar kedua yaitu pelayanan Antenatal Care yang tujuan utamanya mencegah komplikasi obstetrik dan memastikan bahwa komplikasi dideteksi sedini mungkin serta ditangani secara memadai (Erni, 2009).

Pelayanan antenatal merupakan pelayanan kesehatan oleh tenaga kesehatan profesional (dokter spesialis kandungan dan kebidanan, dokter umum, bidan dan perawat) kepada ibu hamil selama masa kehamilannya, yang mengikuti program pedoman pelayanan antenatal yang ada dengan titik berat pada kegiatan promotif dan preventif. Hasil pelayanan antenatal dapat dilihat dari cakupan K1 dan K4. Cakupan K1 merupakan gambaran besaran ibu hamil yang telah melakukan kunjungan pertama ke fasilitas pelayanan kesehatan untuk mendapatkan pelayanan antenatal, sedangkan K4 adalah gambaran besaran ibu hamil yang mendapatkan pelayanan ibu hamil sesuai dengan standar serta paling sedikit empat kali kunjungan, dengan distribusi satu kali pada trimester pertama, satu kali pada trimester dua dan dua kali pada trimester ketiga (Profil Dinkes Palembang, 2010) .

Selama tahun 2006 sampai tahun 2017 cakupan pelyanan kesehatan ibu hamil K4 cenderung meningkat. Jika di bandingkan dengan target Rencana Strategis (Renstra) kementerian Kesehatan Tahun 2017 yang sebesar $76 \%$, capaian tahun 2017 telah mencapai target tahun tersebut yaitu 87,3\% walaupun masih terdapat 11 provinsi yang belum mencapai target.

Sebagai seorang tenaga kesehatan, bidan dituntut mampu memberikan pelayanan kesehatan yang standar seperti diatur dalam Permenkes No. 369/MENKES/III/2007 tentang standar profesi Bidan yaitu "Bidan memberikan asuhan antenatal bermutu tinggi untuk mengoptimalkan kesehatan selama kehamilan yang meliputi deteksi dini, pengobatan ataupun rujukan dari komplikasi tertentu" (Kep Menkes RI 2007).

Jumlah kematian ibu tahun 2017 di Kota Palembang berdasarkan laporan sebanyak 7 orang dari 27.876 kelahiran hidup (Profil Pelayanan Kesehatan Dasar, 2017). Penyebabnya kematian terbanyak adalah hipertensi dalam kehamilan $72 \%$ (5 orang), dan terendah adalah perdarahan $14 \%$ (1 orang). Sedangkan penyebab kematian ibu lainnya 
Jurnal Kebidanan : Jurnal Medical Science Ilmu Kesehatan Akademi Kebidanan Budi Mulia Palembang Volume.9 No.1, Juni 2019

adalah gangguan metabolik (DM) yaitu sebanyak 1 (satu) orang, dan salah satu upaya untuk menurunkan angka kematian tersebut dengan melakukan asuhan antenatal yang terstandar, berdasarkan laporan dinas kesehatan kota Palembang Cakupan K1 untuk Kota Palembang Tahun 2016 sebesar 98,44\% dan K4 sebesar 95,95\% dan Cakupan K1 untuk Kota Palembang Tahun 2017 sebesar 99,96\% dan K4 sebesar 98,97\% (Profil Dinkes Palembang, 2017)

Dari pernyataan tersebut dapat dilihat juga selisih antara K1 dan K4, yang semakin menurun dari tahun ke tahun, menunjukkan bahwa semakin banyak ibu hamil yang melakukan kunjungan pertama pelayanan antenatal diteruskan hingga kunjungan keempat pada trimester ketiga kehamilannya dapat terus dipantau oleh petugas kesehatan yang memiliki kompetensi kebidanan ( Profil Dinkes Palembang, 2010).

Banyak faktor yang mempengaruhi ibu hamil untuk memeriksaan kehamilan (ANC) antara lain paritas ibu, usia ibu, pengetahuan, sikap ibu, ekonomi,sosial budaya, dukungan keluarga, keadaan geografis dan, informasi yang didapat oleh ibu mengenai pemeriksaan kehamilan (Suparyanto, 2011).

Hubungan antara umur ibu dengan frekuensi pemeriksaan kehamilan yaitu, jika semakin cukup umur , tingkat kematangan seseorang akan lebih di percaya daripada orang yang belum cukup tinggi kedewasaannya, jika kematangan usia seseorang cukup tinggi, maka pola berfikir seseorang akan lebih dewasa. Ibu yang mempunyai usia produktif akan lebih berpikir secara rasional dan matang tentang pentingnya melakukan pemeriksaan kehamilan (Suparyanto,2011). Umur yang tidak beresiko tinggi pada saat kehamilan dan persalinan yaitu umur 20-35 tahun karena pada usia ini rahim sudah siap menerima kehamilan, mental sudah mampu merawat bayi dan dirinya dan lebih memperhatikan kehamilannya, sedangkan umur ibu $<20$ tahun rahim dan bagian tubuh lainnya belum siap untuk menerima kehamilan dan ibu cenderung kurang memperhatikan pemeriksaan kehamilannya. Umur ibu yang >35 tahun, maka rahim, bagian tubuh lainnya, fungsinya, serta kesehatan menurun (Murniati, 2008).
Paritas 1 dan paritas tinggi (lebih dari 3) mempunyai angka kematian maternal lebih tinggi. Lebih tinggi paritas, lebih tinggi pula kematian maternal. Resiko pada paritas 1 dapat ditangani dengan asuhan obstetri lebih baik, sedangkan resiko pada paritas tinggi dapat dikurangi atau dicegah dengan keluarga berencana. Sebagian kehamilan pada paritas tinggi adalah tidak direncanakan (Murniati, 2008). Ibu yang pernah melahirkan mempunyai pengalaman tentang ANC, sehingga dari pengalaman yang terdahulu kembali dilakukan untuk menjaga kesehatan kehamilannya (Suparyanto, 2011).

Data kunjungan pemeriksaan kehamilan di Klinik Budi Mulia Medika pada tahun 2017 terdapat 729 ibu hamil yang memeriksakan kehamilannya dan meningkat menjadi 887 pada Januari-September tahun 2017 (Data kunjungan ANC Klinik Budi Mulia Medika, 2017).

Dari data-data di atas, maka peneliti tertarik untuk melakukan penelitian dengan judul Hubungan antara paritas dan umur ibu hamil dengan frekuensi pemeriksaan kehamilan di Klinik Budi Mulia Medika Palembang Tahun 2017.

\section{METODE PENELITIAN}

Penelitian ini menggunakan metode survei analitik dengan rancangan Cross Sectional dimana variabel umur dan paritas ibu serta variabel frekuensi pemeriksaan kehamilan hanya diobservasi dan diambil satu kali saja dalam waktu bersamaan pada saat penelitian (Notoatmodjo, 2005)

Populasi adalah keseluruhan objek penelitian atau objek yang diteliti (Notoatmodjo, 2005).Populasi dalam penelitian ini adalah semua ibu hamil trimester III yang memeriksakan kehamilannya di klinik budi mulia medika Palembang tahun 2017 yang berjumlah 279 ibu hamil dengan jumlah sampel 164 ibu hamil menggunakan teknik simple random sampling.

Analisa univariat adalah analisa yang dilakukan untuk mengetahui distribusi frekuensi variabel independen dan variabel dependen dari hasil penelitian. Pada umumnya dalam analisa ini hanya menghasilkan distribusi dan presentase dari tiap variabel (Notoatmodjo, 2005). 
Jurnal Kebidanan : Jurnal Medical Science Ilmu Kesehatan Akademi Kebidanan Budi Mulia Palembang Volume.9 No.1, Juni 2019

Analisa univariat pada penelitian dilakukan terhadap tiap variabel penelitian yaitu variabel dependen (frekuensi pemeriksaan kehamilan) dan variabel independen (umur dan paritas) yang dianalisis dengan menggunakan tabel distrbusi frekuensi.

\section{HASIL PENELITIAN}

a. Analisa Univariat

Tabel 1 Distribusi Frekuensi Pemeriksaan Kehamilan Pada Ibu Hamil di Klinik Budi Mulia Medika Palembang Tahun 2017

\section{Frekuensi}

No. Pemeriksaan f Persentase Kehamilan

\begin{tabular}{cccc}
\hline 1. & Standar & 124 & 75,6 \\
\hline 2. & Tidak standar & 40 & 24,4 \\
\hline & Jumlah & $\mathbf{1 6 4}$ & $\mathbf{1 0 0}$ \\
\hline
\end{tabular}

Dari tabel 1 dapat dilihat bahwa dari 164 responden, terdapat 124 responden $(75,6 \%)$ dengan frekuensi pemeriksaan kehamilan standar dan 40 responden $(24,4 \%)$ dengan frekuensi pemeriksaan kehamilan tidak standar .

Umur

Tabel 2 Distribusi Frekuensi Berdasarkan Umur Ibu Hamil Di Klinik Budi Mulia Medika PalembangTahun 2017

\begin{tabular}{llcc}
\hline No. & Umur Ibu & f & Persentase \\
\hline 1. & Resiko tinggi & 25 & 15,2 \\
\hline 2. & Resiko rendah & 139 & 84,8 \\
\hline & Jumlah & $\mathbf{1 6 4}$ & $\mathbf{1 0 0}$ \\
\hline
\end{tabular}

Dari tabel 2 dapat dilihat dari 164 responden, didapat responden dengan umur resiko tinggi sebesar 25 responden $(15,2 \%)$, sedangkan responden dengan umur resiko rendah sebesar 139 responden $(84,8 \%)$.

Paritas

Tabel 3 Distribusi Frekuensi Paritas Pada Ibu Hamil Di Klinik Budi Mulia Medika Palembang Tahun 2017

\begin{tabular}{llcc}
\hline No. & \multicolumn{1}{c}{ Paritas } & f & Persentase \\
\hline 1. & Resiko tinggi & 13 & 7,9 \\
\hline 2. & Resiko rendah & 151 & 92,1 \\
\hline & Jumlah & $\mathbf{1 6 4}$ & $\mathbf{1 0 0}$ \\
\hline
\end{tabular}

Dari tabel 3 dapat dilihat dari 164 responden didapat responden dengan paritas resiko rendah sebesar 151 responden $(92,1 \%)$, sedangkan ibu dengan paritas resiko tinggi sebanyak 13 responden $(7,9 \%)$.

b. Analisa Bivariat Hubungan Umur dengan Frekuensi Pemeriksaan Kehamilan Di Klinik Budi Mulia Medika Palembang Tahun 2017. Dilakukan Uji Statistik bivariat antara variabel dependen (frekuensi pemeriksaan kehamilan) dengan variabel independen (umur). Hasil uji statistik dapat dilihat pada tabel 4 di bawah ini.

Tabel 4 Distribusi Frekuensi Umur Ibu dengan Frekuensi Pemeriksaan Kehamilan Di Klinik Budi Mulia Medika Palembang Tahun 2017

\begin{tabular}{|c|c|c|c|c|c|c|c|c|}
\hline \multirow{3}{*}{ No. } & \multirow{3}{*}{ Umur } & \multicolumn{4}{|c|}{$\begin{array}{c}\text { Frekuensi } \\
\text { Pemeriksaan } \\
\text { Kehamilan }\end{array}$} & \multirow{2}{*}{\multicolumn{2}{|c|}{ Jumlah }} & \multirow{3}{*}{$\underset{\text { value }}{p}$} \\
\hline & & \multicolumn{2}{|c|}{ Standar } & \multicolumn{2}{|c|}{$\begin{array}{c}\text { Tidak } \\
\text { standar }\end{array}$} & & & \\
\hline & & $\mathbf{n}$ & $\%$ & $\mathbf{n}$ & $\%$ & $\mathbf{N}$ & $\%$ & \\
\hline 1. & $\begin{array}{l}\text { Reresiko } \\
\text { tinggi }\end{array}$ & 23 & 92 & 2 & 8 & 25 & 100 & \multirow{3}{*}{$\begin{array}{c}0,043 \\
\text { Bermakna }\end{array}$} \\
\hline 2. & $\begin{array}{l}\text { Resiko } \\
\text { rendah }\end{array}$ & 101 & 72,7 & 38 & 27,3 & 139 & 100 & \\
\hline \multicolumn{2}{|c|}{ Jumlah } & 124 & & 40 & & 164 & & \\
\hline
\end{tabular}

Dari tabel 4 diketahui dari 139 responden dengan umur resiko rendah terdapat 101 responden $(72,7 \%)$ dengan frekuensi pemeriksaan kehamilan dengan standar dan 38 responden (27,3\%) dengan frekuensi pemeriksaan kehamilan tidak standar, sedangkan dari 25 responden dengan umur resiko tinggi terdapat 23 responden $(92,0 \%)$ dengan frekuensi pemeriksaan kehamilan standar dan 2 responden $(8,0 \%)$ dengan frekuensi pemeriksaan kehamilan tidak standar. 
Jurnal Kebidanan : Jurnal Medical Science Ilmu Kesehatan Akademi Kebidanan Budi Mulia Palembang Volume.9 No.1, Juni 2019

Berdasarkan hasil uji Chi-square menunjukkan ada hubungan yang bermakna antara umur dengan frekuensi pemeriksaan kehamilan dimana $p$ value $(0,043)<(\alpha$ 0,05), sehingga dapat disimpulkan bahwa ada hubungan bermakna antara umur ibu dengan frekuensi pemeriksan kehamilan di Klinik Budi Mulia Medika Palembang Tahun 2017.

Hubungan Paritas Ibu dengan Frekuensi Pemeriksan Kehamilan Di Klinik Budi Mulia Medika Palembang Tahun 2017.

Tabel 5 Distribusi Frekuensi Paritas Ibu dengan Frekuensi Pemeriksaan Kehamilan Di Klinik Budi Mulia Medika Palembang Tahun 2017

\begin{tabular}{|c|c|c|c|c|}
\hline \multirow{2}{*}{ Paritas } & \multicolumn{2}{|c|}{$\begin{array}{c}\text { Frekuensi Pemeriksaan } \\
\text { Kehamilan }\end{array}$} & \multirow[b]{2}{*}{ Jumlah } & \multirow{2}{*}{$p$ value } \\
\hline & Standar & $\begin{array}{l}\text { Tidak } \\
\text { standar }\end{array}$ & & \\
\hline
\end{tabular}

\begin{tabular}{|c|c|c|c|c|c|c|c|c|}
\hline 1. & $\begin{array}{l}\text { Resiko } \\
\text { Tinggi }\end{array}$ & 6 & 46,2 & 7 & 53,8 & 13 & 100 & \multirow[t]{3}{*}{ 0,017 Bermakna } \\
\hline 2. & $\begin{array}{l}\text { Resiko } \\
\text { Rendah } \\
\end{array}$ & 118 & 78,1 & 33 & 21,9 & 151 & 100 & \\
\hline & mlah & 124 & & 41 & & 164 & & \\
\hline
\end{tabular}

Dari tabel 5 diketahui dari 151 responden dengan paritas resiko rendah terdapat 118 responden $(78,1 \%)$ dengan frekuensi pemeriksan kehamilan dengan standar dan 33 responden $(21,9 \%)$ dengan frekuensi pemeriksaan kehamilan tidak standar, sedangkan dari 13 responden dengan paritas resiko tinggi terdapat 6 responden $(46,7 \%)$ dengan frekuensi pemeriksaan kehamilan dengan standar dan 7 responden $(53,8 \%)$ dengan frekuensi pemeriksaan kehamilan tidak standar.

Berdasarkan hasil uji Chi-square menunjukkan ada hubungan yang bermakna antara paritas dengan frekuensi pemeriksaan kehamilan dimana $p$ value $(0,017)<\left(\begin{array}{ll}\alpha & 0,05\end{array}\right)$ sehingga dapat disimpulkan bahwa ada hubungan antara paritas ibu dengan frekuensi pemeriksan kehamilan di Klinik Budi Mulia Medika Palembang Tahun 2017.

\section{PEMBAHASAN}

\section{Frekuensi Pemeriksaan Kehamilan}

Frekuensi pemeriksaan kehamilan adalah jumlah kunjungan ibu hamil untuk mendapatkan pelayanan pemeriksaan kesehatan antenatal minimal 4 kali ke petugas kesehatan sesuai dengan standar yaitu $1 \mathrm{x}$ pada trimester I, $1 \mathrm{x}$ trimester II dan 2x pada trimester III (Sarwono, 2008).

Berdasarkan hasil uji Chi-square didapatkan sampel sebanyak 164 orang yang memeriksakan kehamilan di Klinik Budi Mulia Palembang Tahun 2017dimana ibu dengan frekuensi pemeriksaan kehamilan sesuai dengan standar sebanyak 124 responden $(75,6 \%)$ dan sebanyak 40 responden $(24,4 \%)$ frekuensi pemeriksaan kehamilan tidak standar.

Banyak faktor yang mempengaruhi ibu hamil untuk memeriksakan kehamilannya (Antenatal care) antara lain paritas, umur, pengetahuan, sikap, ekonomi, sosial, budaya, geografis, informasi, dan dukungan dari keluarga.

\section{Hubungan antara Umur dengan Frekuensi}

\section{Pemeriksaan Kehamilan}

Hasil analisa univariat diketahui bahwa ibu hamil dengan umur resiko rendah lebih tinggi sebanyak 139 responden $(84,8 \%)$ dan ibu dengan umur resiko tinggi sebanyak 25 responden $(15,2 \%)$.

Analisa bivariat menunjukkan bahwa 139 responden dengan umur resiko rendah terdapat 101 responden $(72,7 \%)$ dengan frekuensi pemeriksaan kehamilan dengan standar dan 38 responden $(27,3 \%)$ dengan frekuensi pemeriksaan kehamilan tidak standar, sedangkan dari 25 responden dengan umur dengan resiko tinggi terdapat 23 responden $(92,0 \%)$ dengan frekuensi pemeriksaan kehamilan standar dan 2 responden $(8,0 \%)$ dengan frekuensi pemeriksaan kehamilan tidak standar. 
Hasil uji Chi-square diperoleh $p$ value $(0,043)<\alpha(0,05)$, sehingga dapat disimpulkan bahwa ada hubungan yang bermakna antara umur dengan frekuensi pemeriksaan kehamilan di Klinik Budi Mulia Palembang Tahun 2017.

Hasil penelitian ini sejalan dengan penelitian yang dilakukan oleh Ari Mugiarti (2009) di puskesmas Batealit Kabupaten Jepara didapat bahwa $76,7 \%$ ibu yang berusia 20-35 tahun lebih cenderung memeriksakan kehamilannya dengan hasil uji statistik $p$ value $0,02<\alpha$ 0,05 artinya bahwa ada hubungan antara umur ibu dengan frekuensi pemeriksaan kehamilan.

Hal ini didukung oleh penelitian yang dilakukan oleh Murniati (2008), menyatakan usia yang tidak beresiko tinggi pada saat kehamilan dan persalinan yaitu umur 20-35 tahun karena pada umur tersebut rahim sudah siap menerima kehamilan, mental dan sudah mampu merawat bayi dan dirinya, sedangkan umur $<20$ tahun rahim dan bagian tubuh lainnya belum siap untuk menerima kehamilan dan cenderung kurang perhatian terhadap kehamilannya. Ibu yang berumur > 35 tahun rahim dan bagian tubuh lainnya, fungsinya dan kesehatan sudah mulai menurun sehingga ibu mulai malas untuk memeriksakan kehamilannya.

\section{Hubungan antara Paritas Ibu dengan Frekuensi Pemeriksaan Kehamilan}

Hasil analisa univariat didapatkan bahwa ibu yang memiliki paritas resiko tinggi sebanyak 13 responden $(7,9 \%)$ dan resiko tinggi sebanyak 151 responden $(92,1 \%)$. Analisa bivariat menunjukkan 151 responden dengan paritas resiko rendah terdapat 118 responden $(78,1 \%)$ dengan frekuensi pemeriksan kehamilan dengan standar dan 33 responden $(21,9 \%)$ dengan frekuensi pemeriksaan kehamilan tidak standar, sedangkan dari 13 responden dengan paritas resiko tinggi terdapat 6 responden $(46,7 \%)$ dengan frekuensi pemeriksaan kehamilan dengan standar dan 7 responden $(53,8 \%)$ dengan frekuensi pemeriksaan kehamilan tidak standar.Hasil uji Chi-square dimana $p$ value $(0,017)<\alpha(0,05)$, sehingga dapat disimpulkan bahwa ada hubungan yang bermakna antara umur dengan frekuensi pemeriksaan kehamilan di Klinik Budi Mulia Palembang Tahun 2017.

Hasil penelitian ini didukung pula oleh penelitian yang dilakukan oleh Ari Mugiarti, 2009 didapat bahwa 67,4\% ibu dengan jumlah anak $\leq 3$ orang lebih cenderung memeriksakan kehamilannya dengan hasil uji statistik $p$ value $(0,04)<\alpha(0,05)$ yang berarti ada hubungan antara paritas ibu dengan frekuensi pemeriksaan kehamilan.

Hal ini sesuai dengan pendapat Henri (2008) yang menyatakan bahwa paritas tinggi (>3) mempunyai angka kematian maternal lebih tinggi. Lebih tinggi paritas, lebih tinggi kematian maternal. Resiko pada paritas 1 lebih baik dapat ditangani dengan asuhan obstetrik, sedangkan resiko pada Ibu yang mempunyai anak < 3 orang memeriksakan kehamilannya sekitar 58,9\% sedangkan ibu yang mempunyai anak $>3$ orang atau lebih memeriksakan kehamilannya sebanyak $35,6 \%$. Jadi ibu hamil dengan jumlah anak lebih sedikit cenderung akan lebih baik dalam memeriksakan kehamilannya daripada ibu hamil dengan jumlah anak lebih.

\section{KESIMPULAN}

Berdasarkan hasil penelitian di Klinik Budi Mulia Medika Palembang Tahun 2017 yang berjudul hubungan antara umur dan paritas ibu hamil dengan frekuensi pemeriksaan kehamilan dengan sampel 164 responden, maka dapat disimpulkan sebagai berikut :

1. Distribusi frekuensi responden dengan frekuensi pemeriksaan kehamilan dengan standar sebanyak 124 responden $(75,6 \%)$ dan responden dengan frekuensi pemeriksaan kehamilan tidak standar sebanyak yang beresiko sebanyak 40 responden $(24,4 \%)$.

2. Distribusi frekuensi responden yang paritas tinggi sebanyak 13 responden $(7,9 \%)$ dan paritas 'rendah sebanyak 151 responden $(92,1 \%)$

3. Distribusi frekuensi responden yang umur resiko rendah 139 responden $(84,8 \%)$ dan umur resiko tinggi sebanyak 25 responden $(15,2 \%)$

4. Dari hasil uji statistik dimana $p$ value $(0,043)$ lebih kecil dari $\alpha(0,05)$ 
Jurnal Kebidanan : Jurnal Medical Science Ilmu Kesehatan Akademi Kebidanan Budi Mulia Palembang Volume.9 No.1, Juni 2019

didapatkan bahwa terdapat hubungan yang bermakna antara umur dengan frekuensi pemeriksaan kehamilan.

5. Dari hasil uji statistik dimana $p$ value $(0,017)$ lebih kecil dari $\alpha(0,05)$ didapatkan bahwa terdapat hubungan yang bermakna antara paritas dengan frekuensi pemeriksaan kehamilan.

\section{SARAN}

1. Bagi Pihak Klinik Budi Mulia Palembang

Agar dapat lebih meningkatkan kesadaran ibu-ibu untuk memeriksakan kehamilannya guna mencegah terjadinya berbagai komplikasi pada ibu maupun pada janin sehingga dapat menurunkan angka kejadian morbiditas dan mortalitas ibu dan janin di Klinik Budi Indah Palembang Tahun 2011.

2. Bagi Peneliti yang Akan Datang

Bagi peneliti yang akan datang diharapkan agar dilakukan penelitian lanjutan mengenai frekuensi pemeriksan kehamilan dengan variabel dan tempat penelitian yang berbeda.

\section{DAFTAR PUSTAKA}

Ambarwati, ratna eny, dkk. 2009. Kebidanan Asuhan Komunitas. Yogyakarta : Nuha Medika.

Bandiyah, siti. 2009. Kehamilan, Persalinan dan Gangguan Kehamilan.Yogyakarta : Nuha Medika.

Data Rekam Medik Klinik Budi Mulia Medika Palembang Tahun 2017

Dinkes Kota Palembang, 2017. Profil Kesehatan Provinsi Sumatera Selatan 2017. Palembang: Dinas Kesehatan.

Dinkes Kota Palembang. 2017. Profil Kesehatan Provinsi Sumatera Selatan 2017. Palembang: Dinas Kesehatan. (www.dinkes.palembang.go.id)

Dinkes Kota Palembang. 2016. Profil Kesehatan Provinsi Sumatera Selatan 2017. Palembang: Dinas Kesehatan. (www.dinkes.palembang.go.id)

Hasil Riset Kesehatan Dasar (Rikesdas) 2010.
Kep Menkes RI. 2007. Standar Profesi Bidan no. 369 / Menkes / SK /III. Jakarta: Pengurus IBI 2007.

Kusmiyati, yuni. 2009. Perawatan Ibu Hamil. Yogyakarta: Fitramaya.

M.A. Hoetomo. 2006. Kamus Bahasa Indonesia. Surabaya : Mitra Pelajar

Notoatmodjo, soekidjo. 2010. Metodologi Penelitian. Jakarta : Rineka Cipta Indonesia.

Prawirohardjo,Sarwono. 2011. Ilmu Kebidanan. Jakarta: PT. Bina Pustaka.

Salmah. 2006. Asuhan Kebidanan Antenatal. Jakarta: EGC.

Sulistiani, Maria. 2011. Hubungan antara Pengetahuan dan Paritas ibu dengan Frekuensi Kunjungan Pemeriksaan Kehamilan di Puskesmas. KTI. Akademi Kebidanan Mulia Palembang.

Yulifah, rita, dkk. 2012. Asuhan Kebidanan Komunitas. Jakarta : Salemba Medika.

Mugiarti, Ari. 2008._Hubungan beberapa faktor ibu dengan pemeriksaan kehamilan (K4) di Kecamatan Batealit Kabupaten Jepara Oktober_-Desember.Skripsi. (www.kumpulan skripsi.pemeriksaan kehamilan.2008.ac.id.html)

Angka Kematian Ibu di Sumatera Selatan Selatan

(http://www.tempo.co/read/news/2008/02/0 1/058116685/Angka-Kematian-Ibu- di-Sumatera-Selatan-Masih-Tinggi)

Angka Kematian Ibu Melahirkan Sumsel Tinggi. (http://www.republika.co.id/berita/breakingnews/nasional/09/01/07/24585- angkakematian-ibu-melahirkan-sumsel-tinggi).

Faktor-faktor yang mempengaruhi kontak ibu hamil dengan tenaga kesehatan. (http://drsuparyanto.blogspot.com/2011/02/konsepanc-ante-natal-care.html). 